\title{
バドミントン用アーム式発射マシンの開発
}

酒井 忍 ${ }^{* 1}$, 白山 広樹 ${ }^{* 2}$

\section{Development of arm-type launching machine for badminton}

\author{
Shinobu SAKAI ${ }^{* 1}$ and Hiroki SHIRAYAMA ${ }^{* 2}$ \\ ${ }^{* 1}$ Department of Mechanical Engineering, Kanazawa University \\ Kakuma-machi, Kanazawa-shi, Ishikawa 920-1192, Japan \\ ${ }^{* 2}$ Power System Management Department, Hokuriku Electric Power Company \\ 15-1 Ushijima-cho, Toyama-shi, Toyama 930-8686, Japan
}

\section{Received 7 July 2014}

\begin{abstract}
Badminton shuttlecock has a complicated shape consisting of 16 goose feathers from a waterfowl and a hemispherical cork. Also, the specific air resistance of the shuttlecock is large and its mass is lightweight, weighing approximately $5.2 \mathrm{~g}$. When the shuttlecock is hit with a racket or launched by a machine at speeds higher than an initial velocity of $30 \mathrm{~m} / \mathrm{s}$, the feather parts of the shuttlecock are typically damaged or broken by large impulse load. In this study, a badminton launching machine using a revolving launch arm has been developed with a new launcher mechanism that can discharge at high speeds to reduce the damage to the shuttlecock feathers. The launcher mechanism of the shuttlecock was rotated at a high speed from the launch arm, which held the shuttlecock with a grip tool at the end of the arm rod. The results of the launching experiments using the arm-type badminton machine show that the machine can project the shuttlecock the highest at initial speeds of 36.0 $\mathrm{m} / \mathrm{s}$, with a maximum flight distance of approximately $9.2 \mathrm{~m}$ and the standard deviation of the shot and lateral directions of $0.30 \mathrm{~m}$ and $0.17 \mathrm{~m}$, respectively. In addition, the dimension and the shape of the grip tool with the shuttlecock were examined to determine their influence on the launching performance of the badminton machine.
\end{abstract}

Key words : Sport engineering, Badminton, Launching machine, Mechanism, Motion control, Flight trajectory

\section{1. 緒言}

球技スポーツの一つであるバドミントンは，世界で 160 ケ国，2,000 万人以上の愛好者がいるとも言われ，愛好 者の年齢構成も小学生から高齢者まで非常に幅広い(Alam, et al., 2009). 現在市販されているバドミントン選手用 のラケットの質量は $90 \mathrm{~g}$ 程度しかなく, これは, 硬式テニス用ラケットの約 $1 / 3$ の軽さで小学生でも容易にスイ ングできる．また，シャトルコック（以下，シャトル）を上方に向けて相手と互いにラケットで打ち合えば，比 較的容易にラリーを継続することができるため，多くの人が手軽に楽しめる身近なスポーツである，一方，競技 としてのバドミントンは, オリンピックの正式種目でもあり，世界のトップレベル選手のスマッシュの初速は 83 $\mathrm{m} / \mathrm{s}(300 \mathrm{~km} / \mathrm{h})$ を超え，これは球技スポーツ中の球の飛行速度としては最速である. バドミントンは，スマッシ ユやハイクリア等の打法 (ストローク) 技術に加え, 瞬発力や持久力等の運動能力, さらには高い視覚能力も必 要とされる極めて奥深いスポーツである.

バドミントンで使用されるシャトルは, 半球状のコルクとガチョウ等の天然の水鳥の羽根 16 枚で構成され, そ の最大の特徵は, 大きな空気抵抗力による飛行速度の緩急差である. スマッシュ時, 初速 $67 \mathrm{~m} / \mathrm{s}$ で打撃されたシ ヤトルは, 相手コートに落下寸る僅か 0.6 秒後には $7 \mathrm{~m} / \mathrm{s}$ 前後の速度にまで減速をする(Hubbard and Cooke, 1997). この大きな速度差は，他の球技スポーツでは見られないものであり，このスピード感こそがバドミントンの最大 の魅力の一つでもある.

No.14-00366 [DOI: 10.1299/transjsme.14-00366], J-STAGE Advance Publication date : 14 January, 2015

${ }^{* 1}$ 正員，金沢大学 理工研究域 機械工学系（广929-1192 石川県金沢市角間町）

*2 北陸電力 (株) 電力流通部 (下930-8686 富山県富山市牛島町 15-1)

E-mail of corresponding author: sakai@se.kanazawa-u.ac.jp 
バドミントンに関する先行研究としては，シャトルが複雑形状かつ大きな空気抵抗係数を有するため，風洞実 験を中心にその空力特性や飛行特性, 飛翔軌道等を解明する流体力学分野の研究が数多く行われてきた(Cooke, 1999, 2002), (綿貫, 鈴木, 2006), (Kitta, et al.,2011), (板倉,古村, 2013)。また，スマッシュやハイクリア等の各ストロ 一クにおける三次元動作解析やバイオメカニクス的な観点からの研究も行われている (湯他, 1993), (Marshall and Elliott, 2000). もちろん, バドミントンにおける各種のストローク習得法を中心に, 様々な練習方法に関する研 究も多数行われている (蘭, 2000), (Wonisch, et. al., 2003). しかしながら, これらの練習法はあくまで練習相手が存 在することが前提条件であり，身近に優れたストローク技術や高い運動能力を有する監督や選手等がいない環境 下では全く行うことができない，このような恵まれた環境を持たない選手の場合，練習相手の代わりとなる練習 機が必要不可欠であり, 従来から高性能なバドミントン用練習機が熱望されていた.

現在まで考案または試作されたバドミントン練習機をシャトルの発射機構別に分類すると，ラケット打撃式， 圧縮空気式, バネ・クランク式などがある(Tan, et. al., 2008), (石崎他, 2010), (Yousif and Yeh, 2011). しかし, これら の練習機のほとんどは, シャトルの初速が $30 \mathrm{~m} / \mathrm{s}$ 以下, 最大飛距離が $5 \sim 8 \mathrm{~m}$ 程度であり, 実用的な練習機の発 射性能を満たしているとは言い難い. シャトルの高速発射を阻んでいる最大の要因は, シャトルの特殊性にある. シャトルは, 質量が約 $5.2 \mathrm{~g}$ と超軽量で, 半球状コルクと水鳥の羽根で構成された複雑な形状を有し, 人の手で強 く握れば容易に羽根が変形, 損傷する程度の強度しかない。このような特徵のあるシャトルを初速 $30 \mathrm{~m} / \mathrm{s}$ 以上の 高速で発射することは難しく，仮に発射装置を工夫し発射できたとしても発射時に生ずる大きな衝撃力がシャト ルに負荷されるため，一度の発射でシャトルが損傷または大きく破損する.

このため著者らは，シャトルの中でも比較的強度の高いコルク部を二つの対向するローラで挟持し，その摩擦 力を利用してシャトルを発射する機構の二ローラ式バドミントンマシンの研究開発を行ってきた(酒井他, 2011). 本マシンの発射性能は, 最高初速度 $52 \mathrm{~m} / \mathrm{s}$, 最大飛距離 $11.5 \mathrm{~m} / \mathrm{s}$ であり, 中学生を対象とした実用的な練習機と しては十分な性能があった. しかしながら， $52 \mathrm{~m} / \mathrm{s}$ 以上の高速度で発射させる場合, 必然的にローラを高速回転 させる必要があり, 両ローラによる扇風作用によってシャトルの挿入姿勢が安定せず，発射後の初速度が大きく 変動する問題が生じた. また, シャトルの羽根部がローラに挟持されシャトルが損傷あるいは破損することが, まれではあるが確認された。

そこで本研究では, 従来のシャトル発射法とは異なり, シャトルの損傷を低減しつつ高速発射が可能な新たな 発射機構として，発射アームを回転させてシャトルを投射するバドミントンマシンを考案した．本マシンの発射 機構は, 市販の野球用アーム式ピッチングマシンの投球機構を応用したものであり, 野球ボールの代わりにバド ミントンシャトルをアーム先端の把持具で把持し，その状態でアームを高速に回転させシャトルを投射（発射） する方法である，本論文では，開発したアーム式バドミントンマシンの構造や発射機構，発射実験を通して得ら れた本マシンの発射速度, 飛距離などの発射性能について記述する. また, アーム先端のシャトル把持具の形状 が，本マシンの発射性能に与える影響についても検討する.

\section{2. アーム式バドミントンマシン}

\section{$2 \cdot 1$ アーム式バドミントンマシンの構造と発射機構}

本研究で開発したアーム式バドミントンマシンの外観と代表寸法を図 1 に示寸. 本マシンの基本構造は, 市販 されているアーム式ピッチングマシンとほぼ同様であり, 発射アームを含めたマシン全体の最大寸法は, 縦 1500 $\mathrm{mm}$, 横 $900 \mathrm{~mm}$, 高さ $1815 \mathrm{~mm}$ である. 総重量は約 $200 \mathrm{kgf}$ であり, 多少重いもののマシン下部の四隅には, 固 定装置付の移動用車輪が装着してあるため，マシンの移動や設置は一人でも容易に行える．図 2 にシャトル把持 具付の発射アームの外観と代表寸法を示寸. 発射アームは, クランクシャフトに堅固に固定され, 高さ $1190 \mathrm{~mm}$ の回転軸を中心に回転をする. アームの先端にはシャトルを把持するための把持具があり, 把持具は厚さ $2 \mathrm{~mm}$ のアルミ製プレート 2 枚でアームロッドにボルトで固定されている. このプレートには角度調整用の長穴が空い ており，アームロッドに対して把持具の角度 $\alpha$ を $-40^{\circ} \sim+40^{\circ}$ まで任意に調整することができる.

本マシンの発射機構について述べる. マシン本体の主電源を投入すると, 図 1 に示すモータ (400W, A.C.100V) が一定回転数で運転を開始し，この回転動力はチェーンを介してクランクシャフトにあるスプロケットに伝達さ れる. このスプロケットは, クランクシャフトのメインジャーナル外周に取り付けた玉軸受を介して取り付けら 


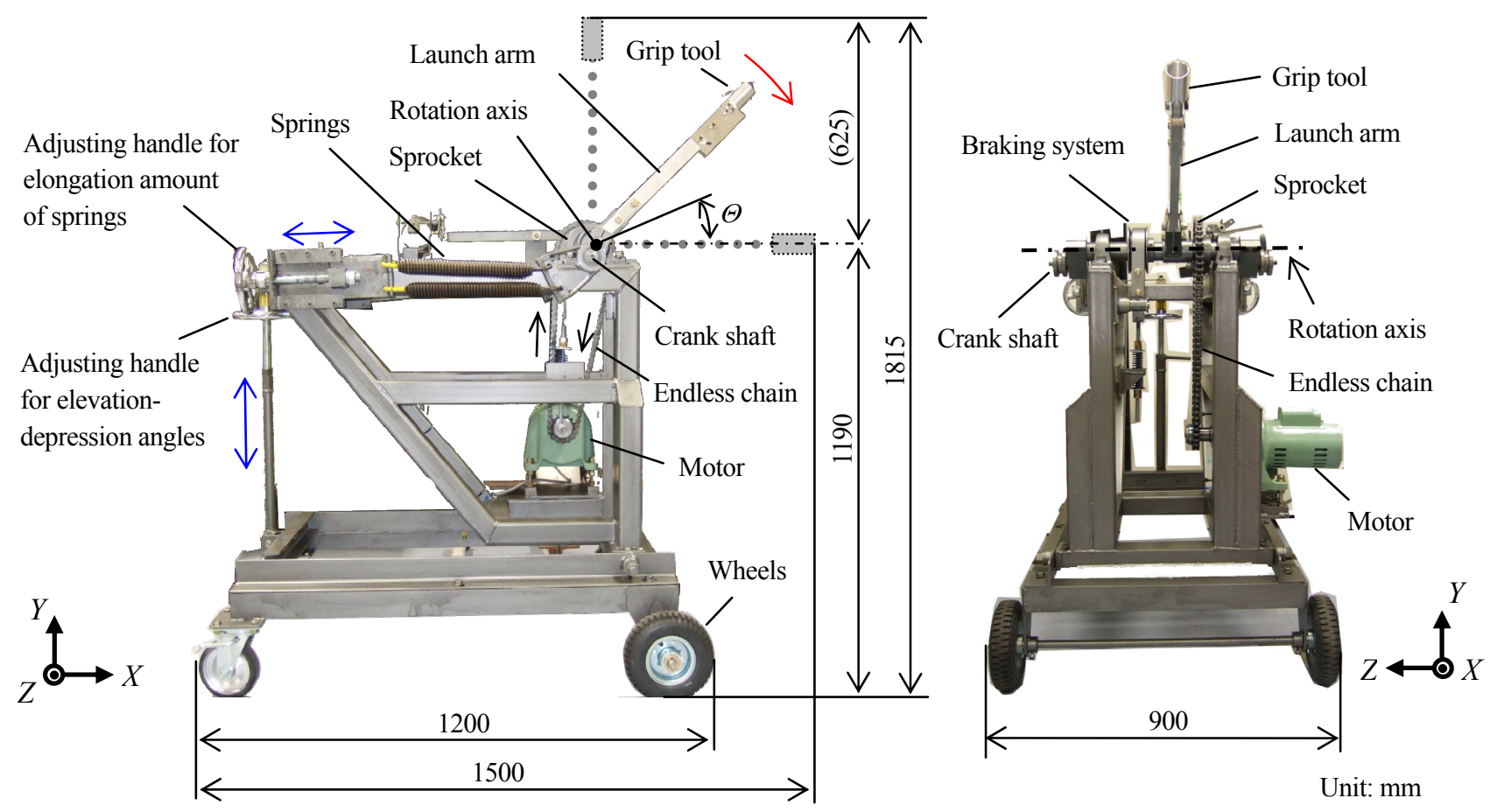

Fig. 1 The appearance and dimensions of the arm-type badminton machine are shown. The rotational power of the motor is transformed into the expansion load of the spring for the launching shuttlecock through the chain, sprocket, attached pin, arm rod, and crank shaft. The machine can discharge the shuttlecock in the speed range of $25-40 \mathrm{~m} / \mathrm{s}$.
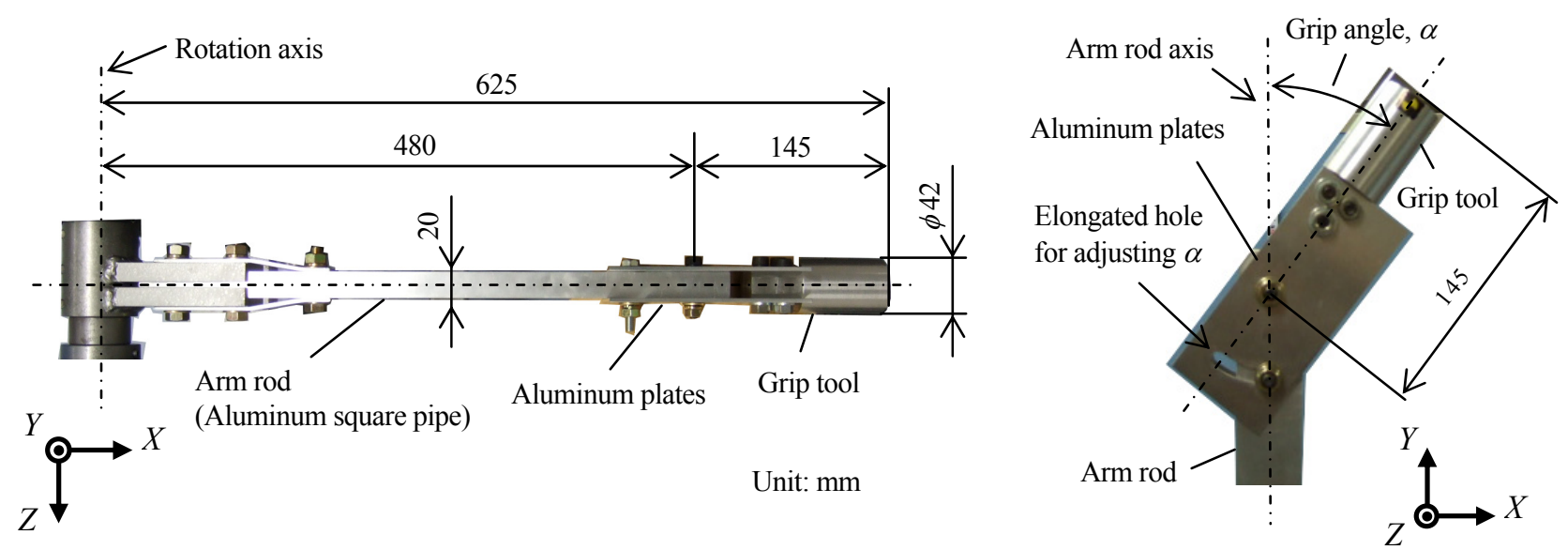

Fig. 2 The appearance and dimensions of the launch arm in the badminton machine are shown. The grip tool at the end of the arm rod can adjust freely from -40 to +40 degrees to the grip angle $\alpha$.

れており，クランクシャフトおよび回転アームの回転運動とは連動しない構造となっている. 他方，スプロケッ トの端面には $\phi 20 \mathrm{~mm}$, 高さ $25 \mathrm{~mm}$ の円筒形のピンが溶接されている. この付属ピンは, 回転アームのアームロ ッドの一部と接触する構造となっている. モータ動力によりスプロケットおよび付属ピンが時計方向に低速回転 (約 $9.2 \mathrm{~min}^{-1}$ ) を開始し鉛直真下付近の角度に達すると, ピンが回転アームのロッド部と接触し, ピンはアーム ロッドを押しながら回転を始める. 回転アームはクランクシャフトに固定されているため, アームの回転運動に 追随してクランクシャフトも同じ速度で回転を始める. 他方, クランクピンは, 長さ $40 \mathrm{~mm}$ のクランクアームに よって支えられており, 左右両側に 2 本ずつ合計 4 本の発射用バネが設置されている. 図 3 は発射機構の概念図 を表わしており, クランクが時計方向に回転している場合, クランクアームの角度が上死点から下死点までは発 射用バネの伸張行程となる. 寸なわち, モータによる回転動力は, チェーン, スプロケット, 付属ピン, アーム ロッド，クランクシャフトを介して，発射用バネの伸張力に変換される. 
Tension process of spring

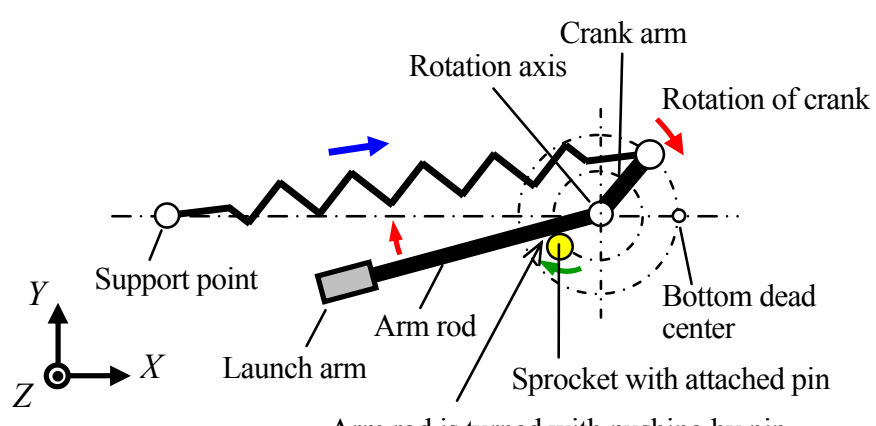

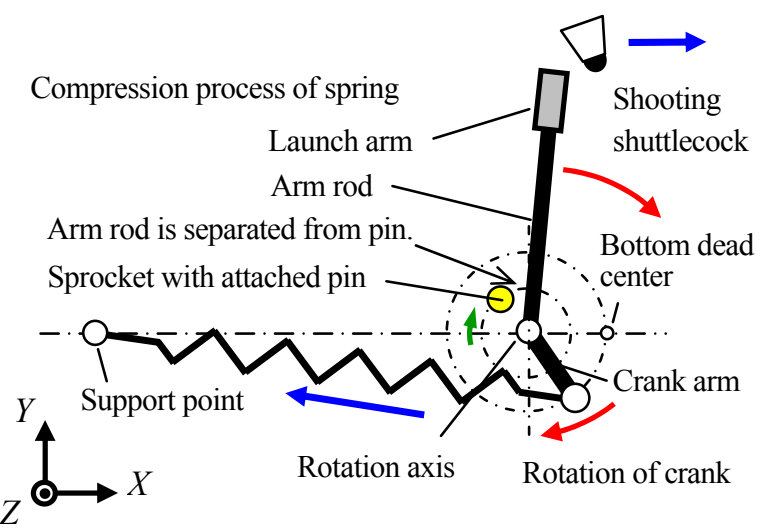

Fig. 3 The schematic of the shuttlecock shooting mechanism of the badminton machine is shown. The left figure shows the tension process of the spring before launch. The right figure shows the compression process of the spring at the time of the shooting shuttlecock.

さらに，スプロケットが回転を続けクランクアームが下死点に達すると，発射用バネの伸びは最大になるそそ の直後, バネが圧縮行程に変わる瞬間，それまで蓄積されたバネの復元力によって，アームロッドは付属ピンか ら離れ，クランクシャフトが時計方向に急激に回転を開始する。 すると，クランクシャフトに固定されている発 射アーム，その先端の把持具もクランク軸を中心に高速で回転し，把持具にセットされていたシャトルが，この 回転力によって把持具から離れ，高速に発射される仕組みとなっている.

シャトルを発射した後, 高速回転している発射アームを減速させるため, クランクシャフトには偏心ロータ機 構を利用した機械式ブレーキ装置が設置されている．シャトル発射後, 発射アームが水平付近に達するとブレー キが利き始め，鉛直真下付近に到達するときは，回転アームの速度はほぼ 0 の停止状態となる，一方，回転アー ムの発射動作とは無関係にモータ，チェーンおよびスプロケットは低速の等速回転を持続しており，スプロケッ トの付属ピンが, シャトルの発射から約 2 3 秒後, 鉛直真下付近で停止中の回転アームのロッド部と再度接触す る. 寸ると再びアームロッドは付属ピンに押されながら回転を始め, 同時に発射用バネも伸張される. クランク 角が下死点に達すると, バネの収縮力によって回転アームが急激に回転し, 把持具からシャトルが高速で発射さ れる．以上の発射サイクルを繰り返し，1 サイクル約 6.5 秒間隔で連続に発射を行うことができる.

なお，開発したバドミントンマシンでは，図 1 に示寸仰角調整ハンドルを回転，調整することにより，アーム 発射部の水平面に対寸る仰俯角 $\Theta$ を+ $8^{\circ} \sim-11^{\circ}$ の範囲で変更させることができる. また, 発射用バネは弾性域 内で使用されており, 使用するバネの種類や本数およびバネ調整ハンドルでバネの初期伸び量 $\delta$ を調節すること によって，シャトルの発射速度を 22〜 40 m/s（80～144 km/h）の範囲で任意に変更することができる.

\section{$2 \cdot 2$ シャトルの装填と把持具}

開発したアーム式バドミントンマシンでシャトルを連続的に発射するには，シャトルを供給する供給装置，発 射アームの回転力を利用してシャトルを把持しつつ発射を行う把持装置（把持具）が必要であり，また発射前に シャトルをこの把持具に装填しなければならない。 シャトル供給装置は，発射アームとは別に本マシンの固定フ レーム上に設けられており，プラスチック製の円錐形リングの一部を切断したシャトル保持具によって，シャト ルは鋁直下向きに保持されるように工夫した.

把持具へのシャトルの装填は, 発射バネの引張行程つまり発射アームが低速回転中に行われ, 発射アームの角 度が水平 $\left(0^{\circ}\right)$ のとき，発射アーム先端の把持具は保持されているシャトルをすくい取り始める．すくい取ら れたシャトルは, アーム角度の増加に伴って把持具内に自重で自然に装填され, アーム角が約 $15^{\circ}$ に達する頃, 把持具内で安定し把持具への装填が完了する. シャトルが装填されていく様子を図 4 に示す.

把持具は，保持されたシャトルをすくい取り，かつ安定して発射する必要があり，本マシンのシャトル発射性 能に大きく影響するものと考えられる. このため予備発射実験を繰返し行い, シャトルを安定して連続に発射で きるシャトルの保持具位置や把持具の形状や寸法について検討をした. その結果，図 5 のような把持具の先端を 


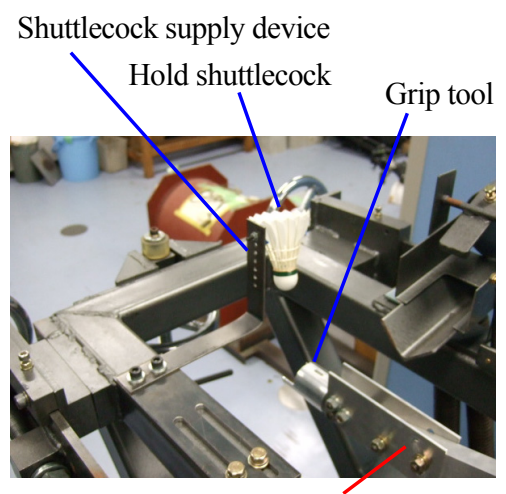

Launch arm
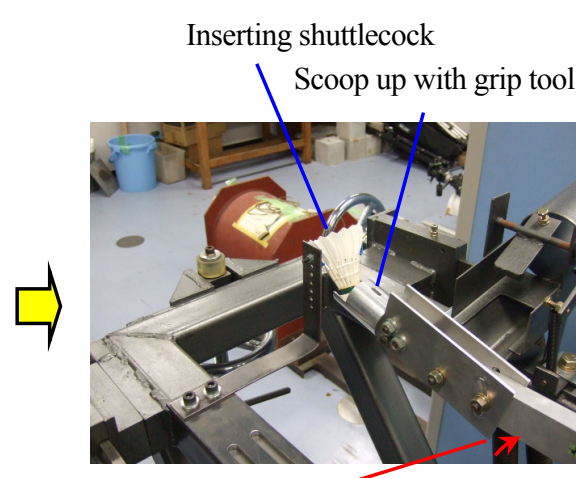

Arm angle (0 degrees)

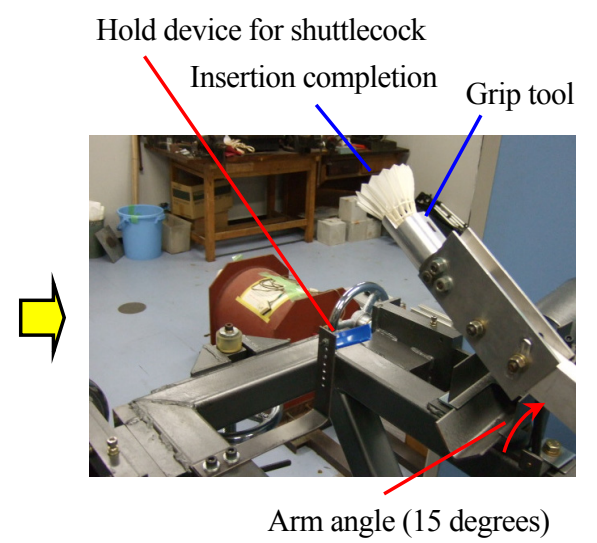

Fig. 4 The inserting motion of the shuttlecock is shown. The shuttlecock is held perpendicular by the hold device. And the shuttlecock is scooped up with the grip tool. When the angle of the launch arm turns of approximately 15 degrees, the shuttlecock is stabilized and the inserting motion to the grip tool is completed.

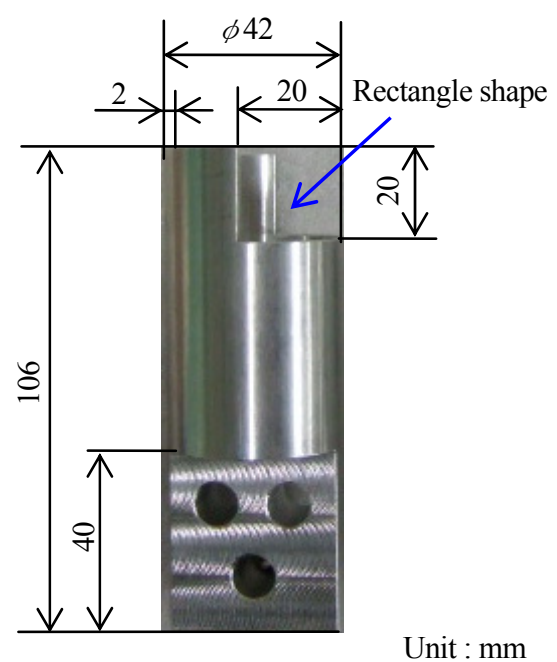

(R-type)

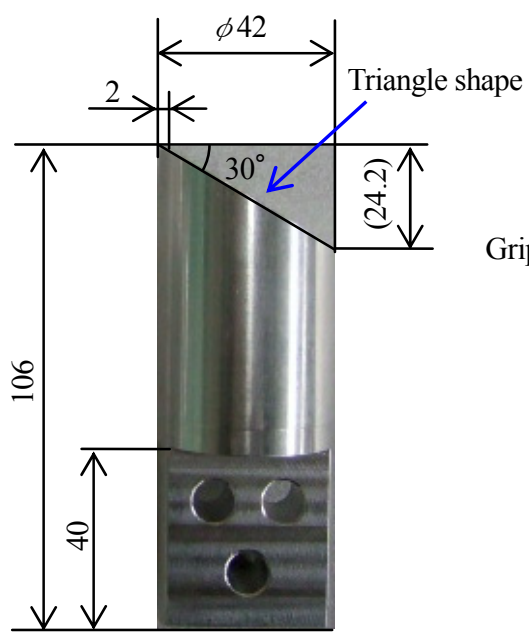

(T-type)

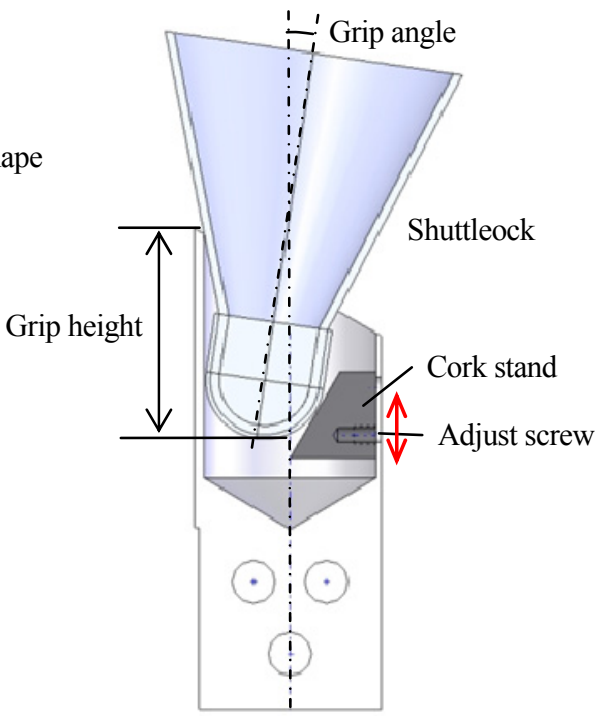

Section in T-type grip tool

Fig. 5 The shapes and dimensions of actual grip tools are shown. The left figure is an R-type shape which cuts the tip into a rectangle. The center figure is a T-type shape which cuts the tip into a triangle. The right figure is a section of the T-type grip tool and inserted shuttlecock. The shuttlecock posture of the grip height and angle are controlled using the adjustment screw in the cork stand.

矩形（R-type）および三角形（T-type）にカットした両形状のものが，スムーズにシャトルが挿入された. そこで, この両タイプを本マシンの把持具として採用した. シャトルを挿入したときの T-type 把持具の断面を図 5 右に示 す.このように両タイプの把持具ともその内部には台形形状のコルク台を設けており，コルク台の側面角度や調 整ねじを用いて把持具長軸に対するシャトルの把持姿勢（把持高さと把持角度）を調節している．なお，本研究 で使用したシャトルは，YONEX 製の水鳥シャトル（第 1 種検定合格球，NEW OFFICIAL 3 番）を用いた。 その 主要寸法等は参考文献(酒井他, 2011)に記載してあるので, ここでは割愛する.

\section{3. アーム式バドミントンマシンの発射性能}

\section{$3 \cdot 1$ 発射アームの発射機構}

アーム式バドミントンマシンのシャトル発射時における発射アームの発射動作を高速度ビデオカメラ（フォト ロン製，FASTCAM SA5）を用いて $1000 \mathrm{fps}$ で撮影した，その一例として，発射バネの初期伸び量 $\delta=22 \mathrm{~mm}$, 把 持具角度 $\alpha=40^{\circ}$ ，T-type 把持具を用いたときのシャトルと発射アームの発射挙動を図 6 に示す。この図は, 発射 アームのアーム角 $\theta_{\text {arm }}$ が $0^{\circ}$ (水平) になる時刻 $T$ を $0 \mathrm{~s}$ (基準) とし， $1 / 100$ 秒毎（10 ms/frame）のストロボ画 
像である. シャトルは $\theta_{\text {arm }}=0^{\circ} \quad(T=0 \mathrm{~ms})$ 付近で把持具に挿入され，低速で回転をしている. $\theta_{\text {arm }}=13.7^{\circ} \quad(T=250$ ms）付近から発射アームの加速が開始され, 発射アームの加速とともに把持されているシャトルも徐々に速度を 増し， $\theta_{\text {arm }}$ が約 $103.5^{\circ} \quad(T=340 \mathrm{~ms})$ に達した時，シャトルは把持具によって発射される. シャトルの加速開始 から発射までに要する時間は約 $90 \mathrm{~ms}$ であった。著者らが既に開発した二ローラ式バドミントンマシン(酒井他， 2011)の発射時間は約 10ms であり，それと比較すると約 9 倍である．発射時のシャトルに発生する動的負荷は， 一般に発射時間が短いほど大きくなるため, 開発したアーム式バドミントンマシンは，シャトル発射時における シャトルの衝撃負荷が小さく，損傷が少なくなるものと予測される.

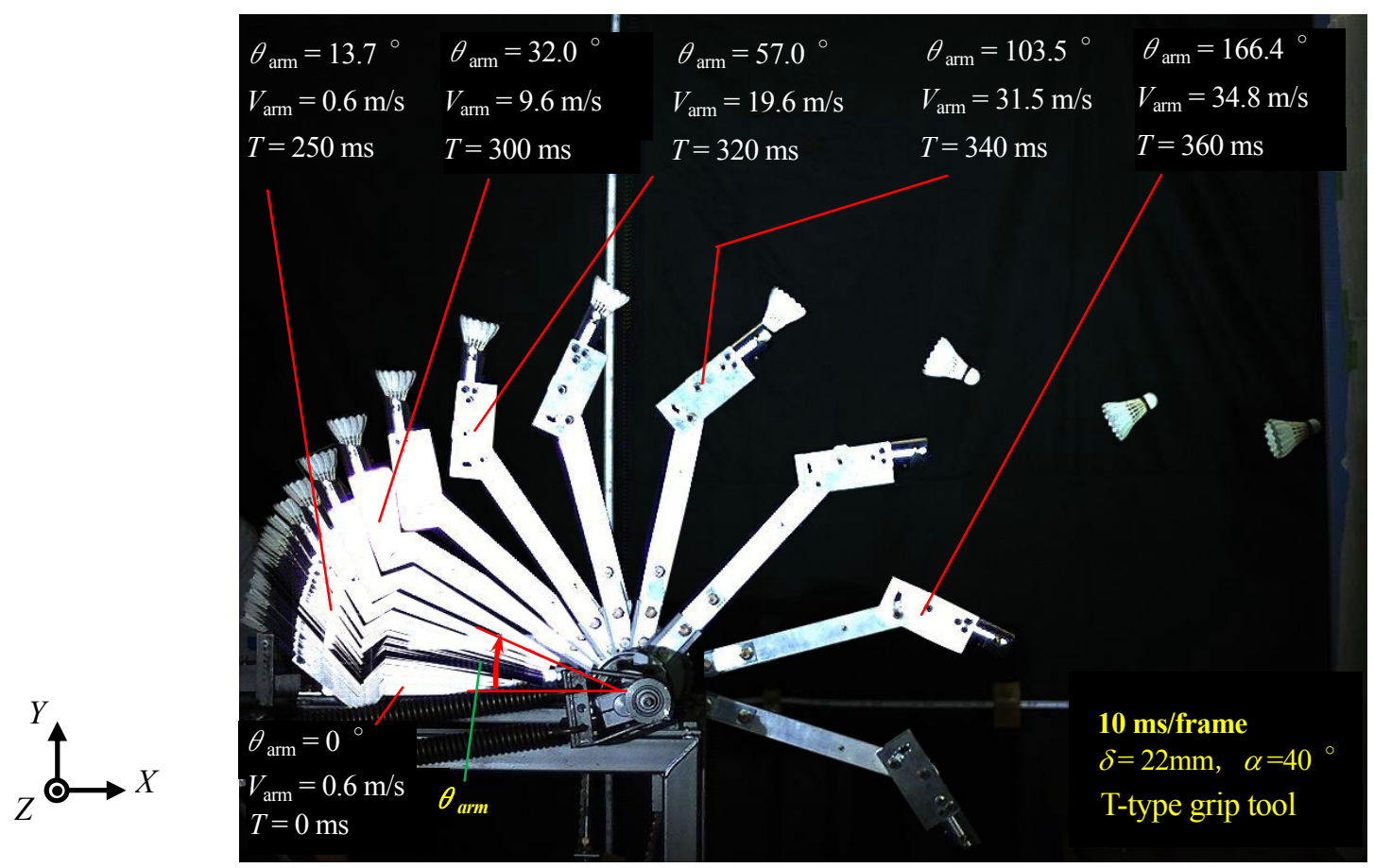

Fig. 6 The stroboscopic image of the motion of the shuttlecock and launch arm during shuttlecock shot is shown. The shot conditions are initial elongation of the shot spring $\delta=22 \mathrm{~mm}$ and grip angle $\alpha=40$ degrees using the T-type grip tool. When the arm angle $\theta_{\text {arm }}=103.5$ degrees $(T=340 \mathrm{~ms})$, the shuttlecock is shot by the launch arm with the grip tool.

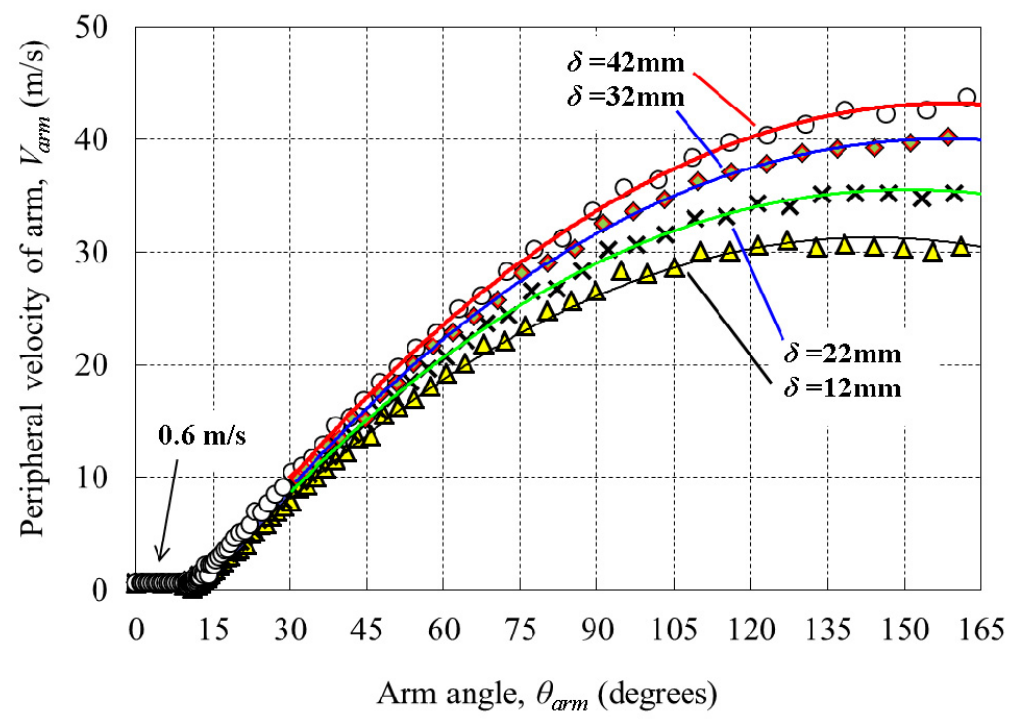

Fig. 7 In the case of an initial elongation of the shot spring $\delta$ is changed 12, 22, 32 and $42 \mathrm{~mm}$, and the relationship between peripheral velocity $V_{\text {arm }}$ and arm angle $\theta_{\text {arm }}$ of the launch arm are shown. If the value of $\delta$ becomes large, the peripheral velocity $V_{\text {arm }}$ of the launch arm is also faster. Regardless of $\delta$, the launch arm reaches its top speed at $\theta_{\text {arm }}$ $=130$ - 150 degrees. 
図 6 の発射画像から発射アームの把持具先端の周速度 $V_{a r m}$ を $2 \mathrm{~ms}$ ごとに算出した. バネの初期伸び量 $\delta$ を 12 , $22 ， 32 ， 42 \mathrm{~mm}$ に変更したときの $V_{a r m}$ と $\theta_{\text {arm }}$ との関係を図 7 に示す. 図より，発射アームは $\delta$ の值に関わらず $\theta_{a r m}$ $=0 \sim 14^{\circ}$ の範囲では $V_{\text {arm }}=0.6 \mathrm{~m} / \mathrm{s}$ の低速回転をしており，この時間中にシャトルが把持具に挿入，把持される. $\theta_{\text {arm }}=14^{\circ}$ 付近でクランクアームが下死点に達し, 発射バネの復元力で発射アームは加速し始める. 発射ア一ムの 加速は $\theta_{\text {arm }}=90^{\circ}$ を超えても続き， $\theta_{\text {arm }}=130 \sim 150^{\circ}$ のとき $V_{\text {arm }}$ は最高速度に達する. また， $\delta$ の值を大きくする と発射アームの周速も速くなっていることがわかる．これより， $\delta$ の值を任意に調整することによって，シャト ルの発射初速度を制御することが可能であると考えられる。

\section{$3 \cdot 2$ アーム式バドミントンマシンとラケット打撃によるシャトルの飛翔挙動と発射速度}

本マシンを用いたシャトル発射時のストロボ画像の一例として， $\delta=42 \mathrm{~mm} ， \mathrm{~T}$-type 把持具を用いて，把持具角 度 $\alpha$ を $30^{\circ}$ および $40^{\circ}$ の場合における発射後のシャトルの飛翔挙動を $4 \mathrm{~ms}$ ごとに表した画像を図 8 (a), (b)にそ れぞれ示す．発射時のシャトルの姿勢は， $\alpha$ の違いで多少異なるもののほぼ鉛直下向きである. 両者とも発射直 後のシャトルには，シャトル姿勢に対する空気抵抗力，揚力，ピッチングモーメントが発生するため，シャトル は紙面（Z方向）に対し，反時計方向に回転をしながら飛翔をする. その後，シャトルはこれらの空気力が一番 低下するような姿勢，つまりコルクが先頭になるような姿勢に変化する．飛翔時間の経過とともに，ピッチング モーメント等の空気力は徐々に減少し，シャトルの飛翔姿勢は，シャトルの長軸方向が飛翔方向と一致するよう になる．図 8 (a)のように発射から 8 フレーム（約 $32 \mathrm{~ms}$ ）後には，シャトル姿勢はほぼ安定した飛翔状態になっ ていることがわかる.

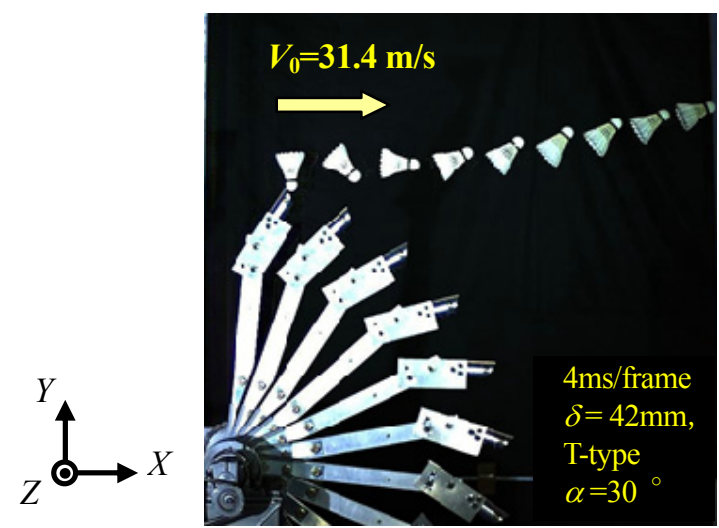

(a) $\alpha=30$ degrees (drive shot)

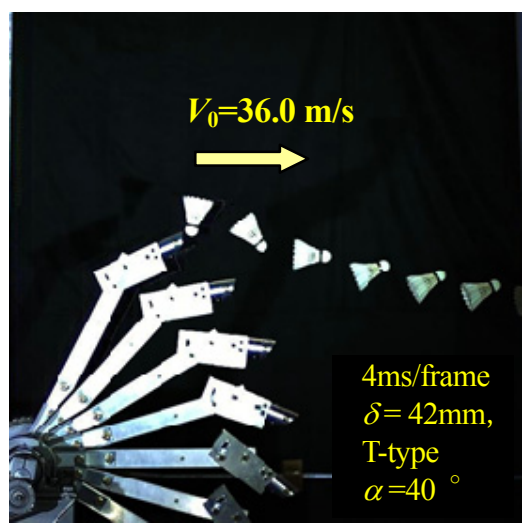

(b) $\alpha=40$ degrees (smash shot)

Fig. 8 The stroboscopic image of the motion of the shuttlecock and launch arm after shuttlecock shot is shown. The shot conditions are $\delta=42 \mathrm{~mm}$, T-type grip tool, grip angle $\alpha=30$ (a) and 40 (b) degrees, respectively. In the case of $\alpha=30$ and 40 degrees, the flight trajectories are drawn for the cases of both the drive and smash shots, respectively.

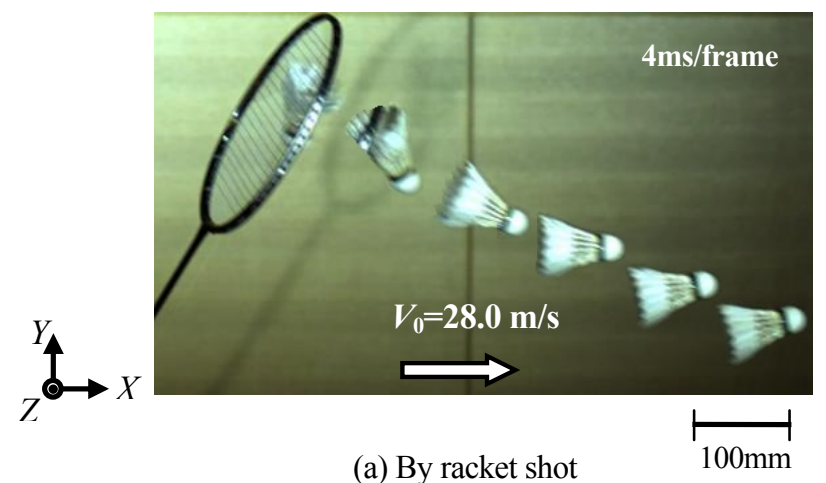

(a) By racket shot

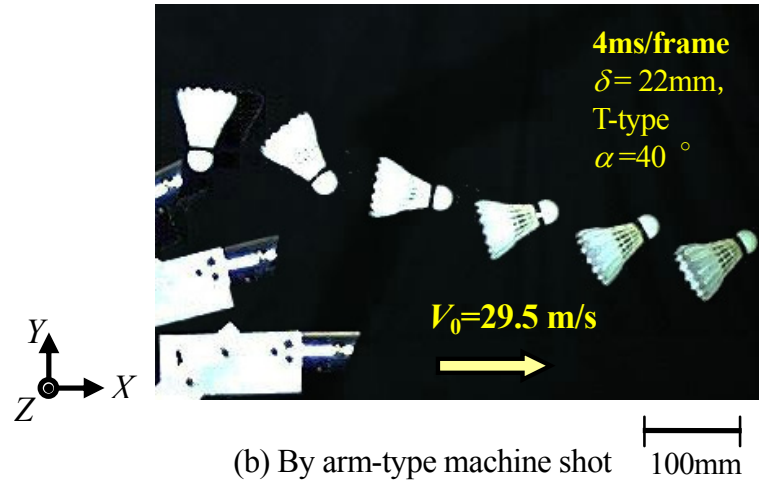

(b) By arm-type machine shot $100 \mathrm{~mm}$

Fig. 9 After the smash shot, flight behaviors of the shuttlecock by racket (a) and arm-type machine (b) are shown. The shot initial speeds $V_{0}$ are (a) $28.0 \mathrm{~m} / \mathrm{s}$ and (b) $29.5 \mathrm{~m} / \mathrm{s}$, respectively. The flight trajectory and posture of the shuttlecock for both shots are similar. It is thought that the arm-type badminton machine can reproduce an actual racket shot. 
本発射実験のストロボ画像からシャトルの発射初速度 $V_{0}$ を算出した. なお, 発射時と発射後 $1 \mathrm{~ms}$ のシャトル のコルク先端の位置座標を $1 \mathrm{~ms}$ で除した值を発射初速度 $V_{0}$ とした. また, 発射仰俯角 $\theta_{0}$ は, 発射時を時刻 $0 \mathrm{~ms}$ とし, その後シャトルの姿勢がほぼ安定する時刻 $32 \mathrm{~ms}$ のコルク先端の位置座標の值から直線近似によって算出 した角度を発射仰俯角 $\theta_{0}$ とした。

図 8 (a) と(b)を比較すると，把持具角度 $\alpha$ が変化するとシャトルの発射仰俯角 $\theta_{0}$ が大きく変化し， $\alpha=30^{\circ}$ では やや上方向に打撃するドライブショット, $\alpha=40^{\circ}$ では下方向に打撃するスマッシュのような飛翔軌道を描いてい ることがわかる，これより，把持具角度 $\alpha$ を制御することによって，バドミントンにおける多様なショットを再 現できることがわかる.

また， $\delta$ の值は両者とも同じであるが，シャトルの発射初速度 $V_{0}$ は異なり， $\alpha=30^{\circ}$ では $V_{0}=31.4 \mathrm{~m} / \mathrm{s}, \alpha=40^{\circ}$ では $V_{0}=36.0 \mathrm{~m} / \mathrm{s}$ となっている. これは, シャトル発射時のアーム角度 $\theta_{\text {arm }}$ と関係しており, $\alpha=30^{\circ}$ の場合, 発 射時の $\theta_{a r m}$ は約 $95^{\circ}, \alpha=40^{\circ}$ の場合 $\theta_{\text {arm }}=115^{\circ}$ であり, このときのアーム速度 $V_{\text {arm }}$ は, 図 $7(\delta=42 \mathrm{~mm})$ からそ れぞれ約 $36,40 \mathrm{~m} / \mathrm{s}$ となっている. これより, シャトルの発射初速度 $V_{0}$ は, アーム速度 $V_{a r m}$ に依存するものと 考えられる. また， $\alpha=30 ， 40^{\circ}$ の $V_{0}$ と $V_{a r m}$ の比を計算すると，それぞれ $0.87 ， 0.90$ であり，アーム速度の約 $90 \%$ がシャトルの発射初速度になっている.

実際のバドミントンラケットを用いて, 初速 $28.0 \mathrm{~m} / \mathrm{s}$ でスマッシュ打撃をしたときのシャトルの飛翔挙動の一 例を図 9(a) に示す.一方, 本アーム式バドミントンマシンを用い, 初速 $29.5 \mathrm{~m} / \mathrm{s}$ のスマッシュの発射条件 $(\delta=22 \mathrm{~mm}$, T-type， $\alpha=40^{\circ}$ ) で発射した時のシャトルの飛翔挙動を図 9(b) に示す. 両図を比較すると, 打撃（発射）後の 飛翔軌道や飛翔姿勢はよく似ており, 本マシンによって発射したシャトルの飛翔挙動は, 実際のラケット打撃と ほぼ同等である．これより，開発したバドミントンマシンは，実戦的練習マシンとして十分使用することができ るものと考えられる.

他方，図9(a) では，ラケット打撃時および打撃直後のシャトルの羽根がやや潰れていることがわかる．これに 対し, 図 9(b) の本マシンによる発射では, シャトルの変形はほとんど認められない. これは, 前節でも述べたが, 本バドミントンマシンではシャトルがゆっくりと加速されて発射されるため, 発射時におけるシャトルの衝撃負 荷や変形が小さくなり, ラケット打撃よりもシャトルが破損し難くなるものと考えられる.

アーム式バドミントンマシンのシャトルの発射初速度 $V_{0}$ および仰俯角 $\theta_{0}$ の結果を図 10,11 にそれぞれ示す. なお，発射実験は同一の発射条件で 5 回行い，その平均值と標準偏差を示している. 図 10 より，把持具タイプ に関わらず $\delta$ おび $\alpha$ が大きくなると $V_{0}$ は速くなる.一方, $V_{0}$ の標準偏差は把持具タイプによって異なり, R-type では約 $1.3 \mathrm{~m} / \mathrm{s}$, T-type では約 $0.6 \mathrm{~m} / \mathrm{s}$ となっており, T-type の方が初速度のバラツキが小さい.

仰俯角 $\theta_{0}$ は, 多少バラツキはあるものの $\delta$ にはあまり関係がなく, ほぼ把持具角度 $\alpha$ で決まる. $\alpha=30^{\circ}$ のとき $\theta_{0}$ は約 $+11^{\circ}, \alpha=40^{\circ}$ のとき $\theta_{0}$ は一 $11^{\circ}$ 前後である. また, $\theta_{0}$ の標準偏差は把持具タイプによってほぼ決定し,

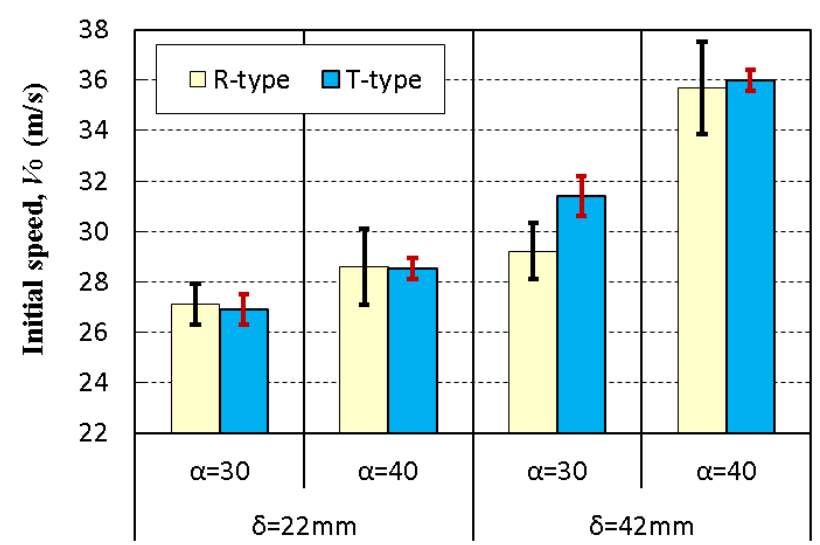

Fig. 10 The shot initial speed $V_{0}$ of the shuttlecock in the arm type badminton machine is shown. $V_{0}$ is fast when $\delta$ and $\alpha$ become large. The standard deviation of $V_{0}$ in the T-type is smaller than in the R-type.

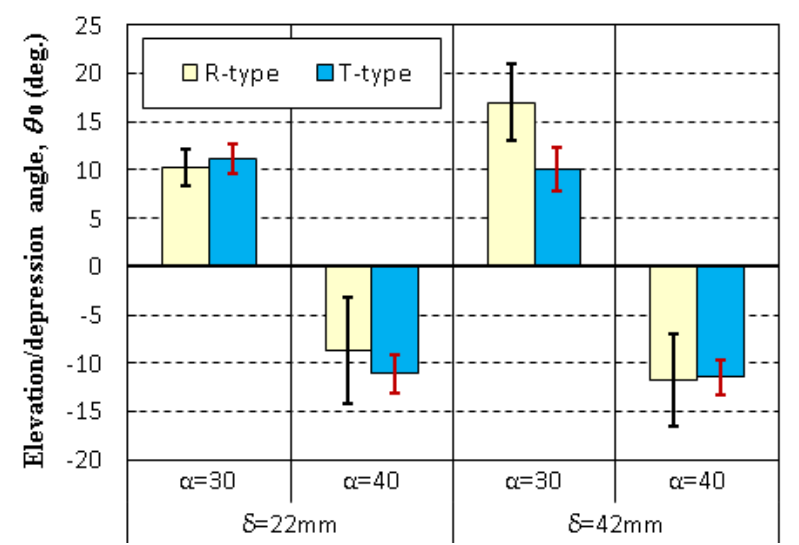

Fig. 11 The elevation-depression angles $\theta_{0}$ in the arm type badminton machine is shown. $\theta_{0}$ is mostly decided by the grip angle $\alpha$. The standard deviation of $\theta_{0}$ in the R-type is larger than in the T-type. 
R-type では約 $4.0^{\circ}$ ，T-type では約 $1.9^{\circ}$ となっており， $V_{0}$ と同様 T-type の方が仰俯角 $\theta_{0}$ のバラツキは小さく安定 していることがわかった.

\section{3 -3 アーム式バドミントンマシンの飛距離と位置精度}

発射バネ伸び量 $\delta=42 \mathrm{~mm}$ ，R-type およびT-type の把持具を用いて，把持具角度 $\alpha$ を $30^{\circ}$ および $40^{\circ}$ のときの 発射後のシャトル落下位置をそれぞれ計測した. なお, 実験は同一発射条件下で 10 球の異なるシャトルで行った. その結果を図 12 に示す. $\alpha=30^{\circ}$ の場合，仰俯角 $\theta_{0}$ は+11 $1^{\circ}$ のドライブショットとなり，飛距離は約 $9 \mathrm{~m}$ であっ た. $\alpha=40^{\circ}$ の場合は， $\theta_{0}$ がー $11^{\circ}$ 前後のスマッシュショットで, 飛距離は $6 \mathrm{~m}$ 程度であった.
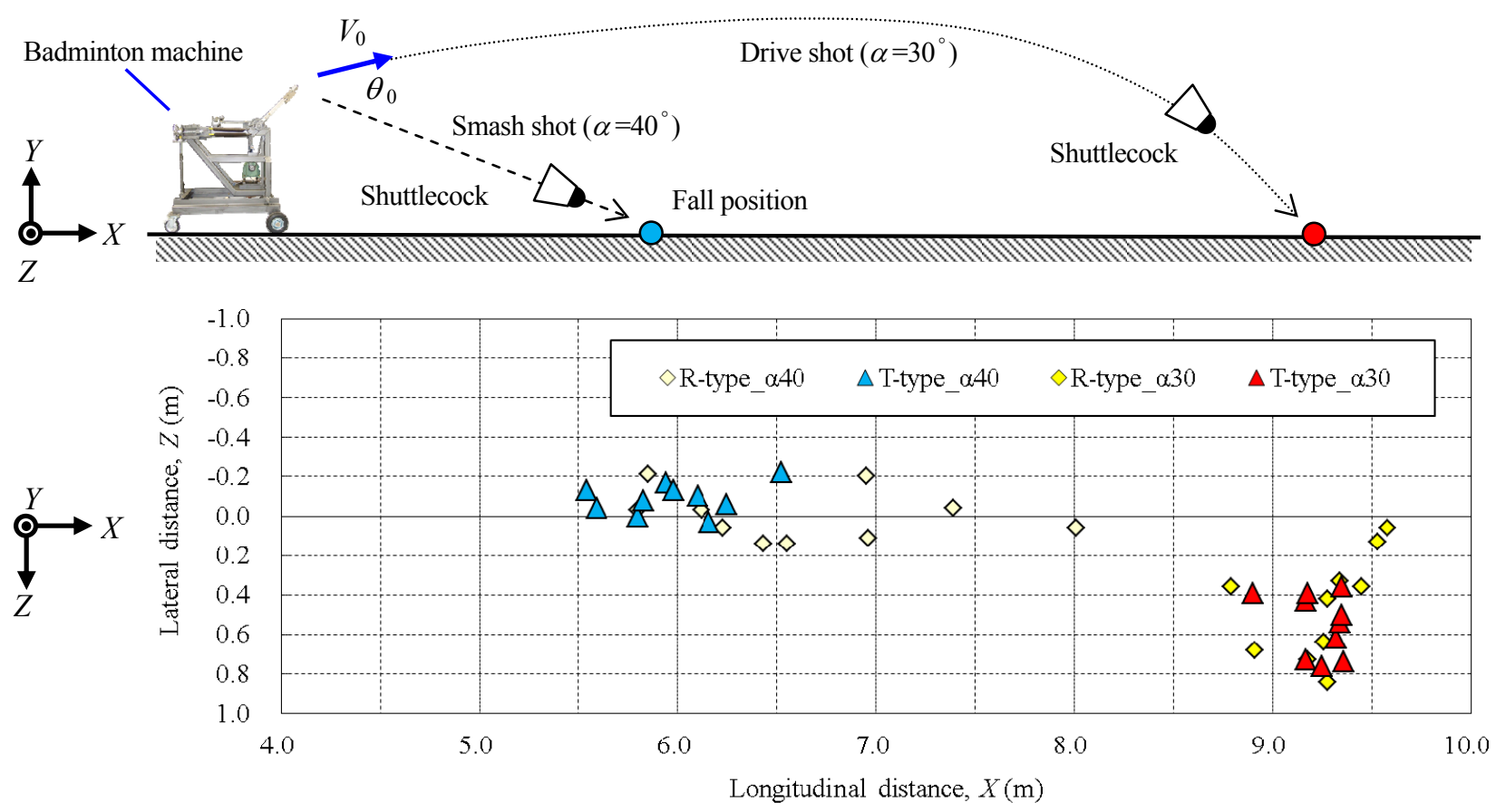

Fig. 12 Measured data of the fall position of the shuttlecock by the arm-type badminton machine is shown. The grip angle $\alpha$ $=40$ and $\alpha=30$ degrees are the short and long distances, respectively. It is thought that the shooting accuracy in the T-type grip tool is higher than in the R-type one.

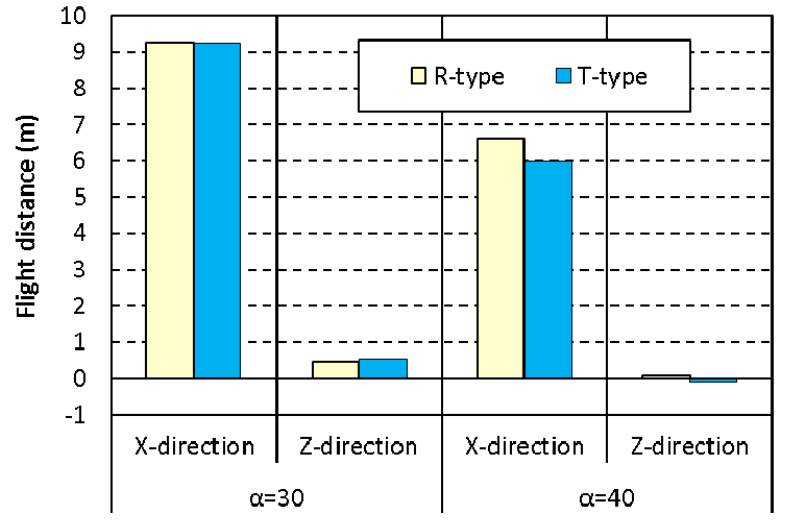

(a) Average of flight distance

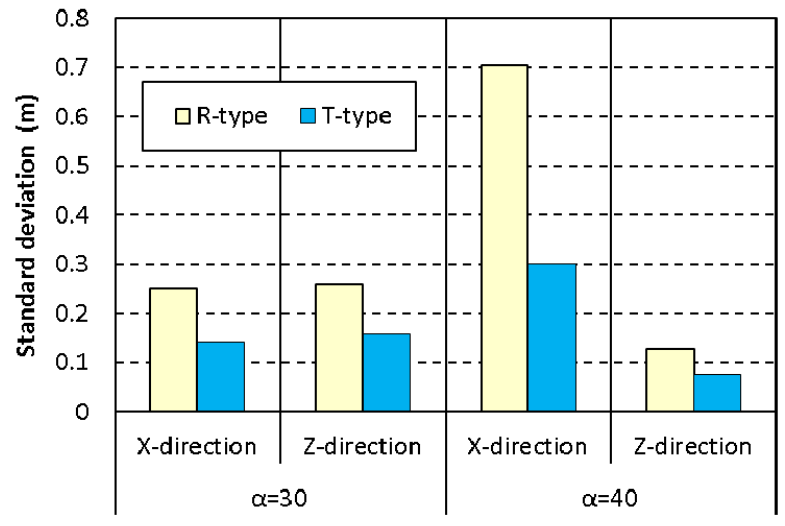

(b) Standard deviation of flight distance

Fig. 13 The average (a) and standard deviation (b) of the flight distance after the shuttlecock shot are shown, respectively. The average flight distances of the R-type and the T-type grip tools are almost the same. The standard deviation of the flight distance of the T-type grip tool is smaller than the R-type one. It is said that the shooting accuracy of the T-type grip tool in the badminton machine is high. 
一方，横方向（ $Z$ 方向）の落下位置に着目すると， $\alpha=40^{\circ}$ のスマッシュではほぼ $Z=0$ で横方向に曲がらず直進 軌道となるが, $\alpha=30^{\circ}$ のドライブでは, マシンから見て右側 $(+Z$ 方向) に $0.5 \mathrm{~m}$ 前後ずれた位置に落下している. これは, シャトルの 16 枚の羽根の重なり状態によって起こるシャトル長軸周りのスピンが影響しており, 横方向 に多少曲がりながら落下寸る三次元の飛翔軌道を描いているものと予測される.

シャトルの落下位置のバラツキを定量的に評価するため，各発射条件における落下位置の発射方向（ $X$ 方向） と横方向（Z方向）の平均飛距離と標準偏差を算出した。 その結果を図 12,13 にそれぞれ示す。これより, 発射 方向および横方向とも平均飛距離は，把持具タイプとは無関係で，把持具角度 $\alpha$ にってほぼ決まることがわか った.

一方, 標準偏差は, 飛距離とは異なる結果になった. $\alpha=40^{\circ}$ の $X$ 方向の標準偏差は, 把持具タイプによらず 他の標準偏差よりも大きい值となっている．シャトルの落下位置は，発射時のシャトルの初速度と仰俯角の変動 が大きく影響するものと予測され, 本発射実験の範囲内では $\alpha=40^{\circ}$ のとき, それらの変動が一番大きくなったこ とがその原因であると考えられる．また，把持具タイプとしては，すべての発射条件下で R-typeよりも T-type の 方が標準偏差は小さくなっている．これより，本バドミントンマシンの把持具タイプとしては，位置精度が高い T-type 把持具を用いる方がよいと言える.

なお，バドミントン練習では，一般にコートを $3 \times 3$ の 9 つのゾーンに分割した領域で実施され，落下位置の 精度としては, 各ゾーンの半分となる発射方向（ $X$ 方向） $1.1 \mathrm{~m}$, 横方向（ $Z$ 方向） $1.0 \mathrm{~m}$ 以内が必要とされる(酒井 他, 2011). 開発したアーム式バドミントンマシンの位置精度は, 把持具タイプに関わらず,最大でも発射方向 $0.71 \mathrm{~m}$, 横方向 $0.27 \mathrm{~m}$ の高い精度を有しており, 高度な練習マシンとして十分使用できるものと考えられる.

\section{4. 結 言}

本研究では, 従来のシャトル発射法とは異なり, シャトルの損傷を低減しつつ高速発射が可能な新たな発射機 構として, 回転式の発射アームを用いたアーム式バドミントンマシンの開発を行った。開発したバドミントンマ シンの発射機構や構造ならびに発射速度, 飛距離などの発射性能について記述した. また, 発射アーム先端のシ ヤトル把持具の形状の違いが，シャトルの発射性能に与える影響について検討した．得られた結言は次の通りで ある。

（1）開発したアーム式バドミントンマシンは，T-type 把持具を用いた場合，最高発射初速度 $36.0 \mathrm{~m} / \mathrm{s}$, 最大飛距離 $9.2 \mathrm{~m}$ ，発射方向 $0.30 \mathrm{~m} ，$ 横方向 $0.17 \mathrm{~m}$ 未満の高い位置精度を有している．また，把持具の角度を変えること により種々のショットが発射可能であり，実用的練習機として十分な性能がある.

(2) アーム式バドミントンマシンの把持具タイプとしては, 仰俯角のバラツキが小さく位置精度の高い T-type 把 持具を用いる方がよい.

今後の課題は，シャトルの発射速度の高速化と多様なショットを両立する最適なシャトルの把持姿勢（把持高 さと把持角度）を明らかにし，本バドミントンマシンのさらなる高性能化を図ることである.

最後に, 本研究の一部は, JSPS 科研費 No.24560255 の助成を受けたものである. ここに謝意を表する. なお, 本研究で述べたアーム式バドミントンマシンの発射機構や構造については, すでに特許登録 (特許第 5403746 号) されていることを申し添えたい.

\section{文献}

Alam, F., Chowdhury, H., Theppadungporn, C., Subic, A. and Khan, M. K., Aerodynamic properties of badminton shuttlecock, International Journal of Mechanical and Materials Engineering, Vol. 4, No. 3 (2009), pp.266-272.

蘭 和真, 競技バドミントンの運動強度: 時間設定方式のゲーム練習と公式試合の運動強度の比較, 東海女子大学 紀要, Vol.20 (2000), pp.179-189.

Cooke, A. J., Shuttlecock aerodynamics, Sports Engineering, Vol.2 (1999), pp.85-96.

Cooke, A. J., Computer simulation of shuttlecock trajectories, Sports Engineering, Vol.5, No.2 (2002), pp.93-105. 
Hubbard, M. and Cooke, A. J., Spin dynamics of the badminton shuttlecock, 6th International Symposium on Computer Simulation in Biomechanics (1997), pp.42-43.

石崎繁利, 田中裕一，鍋野幸大，笠井正三郎，英 崇夫，バドミントン練習機の開発，工学・工業教育研究講演会講 演論文集 平成 22 年度, No.9-107 (2010), pp.188-189.

板倉嘉哉, 古村文音, 身近な遊具等の工学的解析(その 2: バドミントン用シャトルコックのダイナミクス), 千葉 大学教育学部研究紀要, Vol.61 (2013), pp.463-471.

Marshall, R. N. and Elliott, B. C., Long-axis rotation: The missing link in proximal-to-distal segmental sequencing, Journal of Sports Sciences, Vol.18, No.4 (2000), pp.247-254.

酒井 忍, 野辺亮太, 水口さゆり, 村口さよ, 二ローラ式バドミントンマシンの開発, 日本機械学会論文集 C 編, Vol.77, No.781 (2011), pp.3415-3426.

Kitta, S., Hasegawa, H., Murakami, M. and Obayashi, S., Aerodynamic properties of a shuttlecock with spin at high Reynolds number, 5th Asia-Pacific Congress on Sports Technology (APCST), Vol.13 (2011), pp.271-277.

湯 海鳰, 阿部一佳, 加藤幸司, バドミントンのスマッシュ動作の 3 次元動作解析: 前腕と手関節の動きを中心に, 体育学研究, Vol.38, No.4 (1993), pp.291-298.

Tan, J. C. C., Foong, S. K., Veluri, S. and Sachdeva, S., Testing of badminton shuttles with a prototype launcher, The impact of Technology on Sport II (2008), pp. 443-448.

綿貫忠晴, 鈴木宏二郎, バドミントン用シャトルコックの基礎的空力特性，第 38 回流体力学講演会講演論文集 (日本航空宇宙学会), 1B7 (2006), pp.89-92.

Wonisch, M., Hofmann, P., Schwaberger, G., Duvillard, S. P. and Klein, W., Validation of a field test for the non-invasive determination of badminton specific aerobic performance, British Journal Sports Medicine, Vol.37, No.2 (2003), pp.115-118.

Yousif, B. F. and Yeh, K. S., Badminton training machine with impact mechanism, Journal of Engineering Science and Technology, Vol.6, No.1 (2011), pp.61-68.

\section{References}

Alam, F., Chowdhury, H., Theppadungporn, C., Subic, A. and Khan, M. K., Aerodynamic properties of badminton shuttlecock, International Journal of Mechanical and Materials Engineering, Vol. 4, No. 3 (2009), pp.266-272.

Araragi, K., Thephysiological studies on physical demands in competitive badminton: An investigation from the view points of the work intensity of practice games and official games of elite female, Departmental Bulletin Paper, Research Bulletin, Tokai Women's Junior College, Vol.20 (2000), pp.179-189 (in Japanese).

Cooke, A. J., Shuttlecock aerodynamics, Sports Engineering, Vol.2 (1999), pp.85-96.

Cooke, A. J., Computer simulation of shuttlecock trajectories, Sports Engineering, Vol.5, No.2 (2002), pp.93-105.

Hubbard, M. and Cooke, A. J., Spin dynamics of the badminton shuttlecock, 6th International Symposium on Computer Simulation in Biomechanics (1997), pp.42-43.

Ishizaki, S., Tanaka, Y., Nabeno, T., Kasai, S. and Hanabusa, T., Development of practice machine for badminton, Japanese Society for Engineering Education (JSEE) Annual Conference 2010, No.9-107 (2010), pp.188-189 (in Japanese).

Itakura, Y. and Komura, A., Engineering analysis of a familiar plaything (2nd report: dynamics of badminton shuttlecock), Research Bulletin of the Faculty of Education, Chiba University, Vol.61 (2013), pp.463-471 (in Japanese).

Marshall, R. N. and Elliott, B. C., Long-axis rotation: The missing link in proximal-to-distal segmental sequencing, Journal of Sports Sciences, Vol.18, No.4 (2000), pp.247-254.

Sakai, S., Nobe, R., Mizuguchi, S. and Muraguchi, S., Development of launcher machine with two rollers for badminton, Transactions of the Japan Society of Mechanical Engineers, Series C, Vol.77, No.781 (2011), pp.3415-3426. (in Japanese).

Kitta, S., Hasegawa, H., Murakami, M. and Obayashi, S., Aerodynamic properties of a shuttlecock with spin at high Reynolds number, 5th Asia-Pacific Congress on Sports Technology (APCST), Vol.13 (2011), pp.271-277.

Tang, H. P., Abe, K. and Katoh, K., Three-dimensional cinematographical analysis of the badminton forehand smash: movement of the forearm and hand, Japan Journal of Physical Education, Health and Sport Sciences, Vol.38, No.4 (1993), pp.291-298 (in Japanese).

Tan, J. C. C., Foong, S. K., Veluri, S. and Sachdeva, S., Testing of badminton shuttles with a prototype launcher, The impact of Technology on Sport II (2008), pp. 443-448. 
Watanuki, T. and Suzuki, K., The fundamental aerodynamic characteristics of the badminton shuttle cocks, 38th Fluid Dynamics Conference, (The Japan Society for Aeronautical and Space Sciences), 1B7 (2006), pp.89-92 (in Japanese).

Wonisch, M., Hofmann, P., Schwaberger, G., Duvillard, S. P. and Klein, W., Validation of a field test for the non-invasive determination of badminton specific aerobic performance, British Journal Sports Medicine, Vol.37, No.2 (2003), pp.115-118.

Yousif, B. F. and Yeh, K. S., Badminton training machine with impact mechanism, Journal of Engineering Science and Technology, Vol.6, No.1 (2011), pp.61-68. 